Journal of Maternal and Child Health (2019), 4(2): 126-135

https://doi.org/10.26911/thejmch.2019.04.02.08

\title{
Path Analysis on the Determinants of Severe Preeclampsia in Surakarta, Central Java
}

\author{
Prafista Wulan Sari'), Uki Retno Budihastuti²), Eti Poncorini Pamungkasari3) \\ 1)Masters program in Public Health, Universitas Sebelas Maret \\ 2)Department of Obstetrics and Gynecology, Dr. Moewardi Hospital, Surakarta \\ 3)Faculty of Medicine, Universitas Sebelas Maret
}

\begin{abstract}
Background: Preeclampsia is a major cause of maternal morbidity and mortality that occurs at gestational age $>\mathbf{2 0}$ weeks. It is characterized by hypertension and proteinuria. Shortly, severe preeclampsia may develop into eclampsia accompanied by seizures or coma. This study aimed to examine the determinants of severe preeclampsia in Surakarta, Central Java.

Subjects and Method: This was a case control study conducted in Gajahan health center, Dr. Moewardi hospital, and Surakarta hospital, Surakarta, Central Java, from October 2018 to December 2018. A sample of 200 pregnant women was selected by fixed disease sampling. The dependent variable was severe preeclampsia. The independent variables were age, education, stress, parity, history of hypertension, history of diabetes mellitus (DM), ANC visit, and family history of hypertension. Data on preeclampsia were obtained from medical record. The other data were collected by questionnaire. The data were analyzed by path analysis.

Results: Severe preeclampsia was directly and positively associated with age $<20$ or $\geq 35$ years $(b=$ 1.23 ; $95 \% \mathrm{CI}=0.31$ to $2.14 ; \mathrm{p}=0.008)$, history of hypertension $(\mathrm{b}=1.54 ; 95 \% \mathrm{CI}=0.58$ to $2.51 ; \mathrm{p}=$ 0.002), history of $\mathrm{DM}(\mathrm{b}=1.12 ; 95 \% \mathrm{CI}=0.21$ to $2.03 ; \mathrm{p}=0.016)$, and stress $(\mathrm{b}=1.58$; $95 \% \mathrm{CI}=$ 0.60 to $2.56 ; \mathrm{p}=0.002)$. It was negatively associated with parity $(\mathrm{b}=-0.96 ; 95 \% \mathrm{CI}=-1.90$ to $0.01 ; \mathrm{p}=0.046)$ and ANC visit $(\mathrm{b}=-1.98 ; 95 \% \mathrm{CI}=-2.91$ to $-1.05 ; \mathrm{p}<0.001)$. Severe preeclampsia was indirectly associated with education, ANC visit, and family history of hypertension.

Conclusion: Severe preeclampsia is directly and positively associated with age, history of hypertension, history of DM, and stress. It is negatively associated with parity and ANC visit. Severe preeclampsia is indirectly associated with education, ANC visit, and family history of hypertension.
\end{abstract}

Keywords: severe preeclampsia, determinants, path analysis

\section{Correspondence:}

Prafista Wulan Sari. Masters Program in Public Health, Universitas Sebelas Maret. Jl. Ir. Sutami No. 36 A, Surakarta, Central Java. Email: prafistaw@yahoo.com. Mobile: +6285740772699.

\section{BACKGROUND}

The Maternal Mortality Rate (MMR) in Indonesia is still very high. The 2015 Intercensal Population Survey (SUPAS) showed that the Maternal Mortality Rate (MMR) in Indonesia was 305 per 100,000 live births. The target to be achieved by the SDGs (Sustainable Development Goals) is less than 70 maternal deaths per 100,00o live births globally in 2030, the figure is still high, while the AKI in Central Java Pro- vince in 2017 is 88.58 per 100,000 live births or 475 cases. The maternal Mortality Rate (MMR) in Surakarta in 2017 amounted to 71 cases (14.95\%) (Republic of Indonesia Ministry of Health, 2017; Central Java Provincial Health Office, 2018).

Preeclampsia is one of the main causes of maternal and perinatal morbidity and mortality worldwide which affects 2 to $8 \%$ of all pregnancies. Causes of preeclampsia include age, education, parity, ANC visits, family history of hypertension, 
history of hypertension, history of diabetes mellitus, and stress (Jeyabalan, 2013; Grum et al., 2017; Moon and Odibo, 2014; Quan et al., 2018; Tessema et al., 2015; Ramesh et al., 2014; Yu et al., 2013).

Preeclampsia in Indonesia is the second leading cause of maternal death after bleeding, whereas in Central Java the incidence of preeclampsia is the first cause of maternal death. The incidence of preeclampsia in Indonesia in 2013 was 27.1\%, while preeclampsia in Central Java Province in 2017 amounted to $32.97 \%$ (Republic of Indonesia Ministry of Health, 2014; Central Java Provincial Health Office, 2018). Based on the results of the preliminary study that has been carried out at Dr Moewardi hospital, Surakarta on April 2, 2018 through secondary data from medical records, the results showed that the number of occurrences of preeclampsia in Dr.Moewardi hospital in 2016 was 248 patients while in 2017, there were 282 patients.

Preeclampsia is diagnosed when pregnant women experience hypertension and urine protein after 20 weeks of pregnancy. The main predisposing theory of preeclampsia is abnormal placental implantation, resulting in adverse uterine and placental perfusion resulting in hypoxic conditions, increased oxidative stress and the release of anti-angiogenic proteins into maternal plasma (Villa et al., 2017; Grum et al., 2017).

Pregnancy factors that influence the occurrence of preeclampsia include parity. Primiparaus mothers have risk factors for preeclampsia 2-3 times greater compared to multiparous mothers. Preeclampsia in primiparous mothers has a significantly higher risk of hypertensive morbidity in subsequent pregnancies. Antenatal Care (ANC) visits affect preeclampsia because each ANC visit of a mother will get coun- seling during pregnancy that can detect early preeclampsia (Bdolah et al., 2014; Grum et al., 2017).

Factors that influence the occurrence of preeclampsia associated with maternal health history include family history of hypertension, history of hypertension, and a history of diabetes mellitus. Based on research conducted by Grum et al. (2017), it is found that mothers with a family history of hypertension also affected preeclampsia with a risk opportunity 7 times greater than women who did not have a history of hypertension. Research conducted by Quan et al. (2018) shows that maternal comorbidities such as hypertension, diabetes mellitus are high risk factors for preeclampsia. The incidence of preeclampsia among people with diabetes mellitus ranges from $10 \%$ to $20 \%$ (Gutaj et al., 2017).

Apart from the factors above, several studies show that age, education and stress also affect the occurrence of preeclampsia. The increase of maternal age is an important risk because the increase in villous reactions causes preeclampsia in mothers aged $\geq 35$ years and is four times more likely to experience preeclampsia than mothers aged 25-29 years. Pregnant women $<20$ years old are also at risk of developing preeclampsia because of the incomplete maturation of the reproductive system (Tessema et al., 2015; Benli et al., 2014; Cohen et al., 2014). The level of education also affects the occurrence of preeclampsia. Education indirectly represents low socio-economic status and socio-economic determinants (Ramesh et al., 2014). Based on research conducted by $\mathrm{Yu}$ et al. (2013), it is found that mothers who experienced psychosocial stress had a 20 times higher risk of developing preeclampsia. The results of this study indicate the importance of prevention efforts to reduce psychosocial stress. 
The determinants referred to in this study were age, education, parity, ANC visits, family history of hypertension, history of hypertension, history of diabetes mellitus, and stress. Based on this background and the high incidence of severe preeclampsia, the authors are interested in examining further factors that influence the incidence of severe preeclampsia.

\section{SUBJECTS AND METHOD \\ 1. Study Design}

This study is quantitative non-experimental one. The design was an observational analytic study with a case control approach comparison of 1: 3 . The study was conducted at Gajahan community health center, Surakarta Hospital, and Dr. Moewardi hospital, Surakarta, Central Java, Indonesia, from October to December 2018.

\section{Population and Samples}

The target population of this study was all mothers with severe preeclampsia. A sample of 200 pregnant women was selected by fixed disease sampling.

\section{Study Variables}

The dependent variable was severe preeclampsia. The independent variables were age, education, parity, ANC visit, family history of hypertension, history of hypertension, history of diabetes mellitus, and stress.

\section{Operational definition of variables}

Severe preeclampsia was defined as an increase in blood pressure of at least 160 $\mathrm{mmHg}$ systolic or $110 \mathrm{mmHg}$ diastolic with urine protein 5 to $10 \mathrm{~g} / \mathrm{L}$ in 24 hours or $\geq+$ 2 proteins with a dipstick. The data collection was carried out using medical record. The measuring scale for women who did not experience severe preeclampsia is $\mathrm{o}$ and 1 for mothers who had severe preeclampsia.

Age is how long the mother is alive with a life span calculated from birth until data collection is done. The data collection was done with a questionnaire. The measuring scale of $O$ is for mothers aged 20-34 years and 1 is for mothers aged $\geq 35$ years.

Education was defined as the highest formal school level achieved by mothers starting from elementary, junior high school, senior high school and college. The data were obtained using questionnaires. The measuring scale of $o$ is for mothers with education $<$ senior high school education and 1 is for mother with education $\geq$ senior high school.

Parity means a mother with a number of children born both alive and dead. The data collection was conducted using questionnaire. The measurement scale was o for parity 1 and 1 for parity $>1$.

ANC visit was defined as mothers who have ANC examinations during pregnancy. The data collection was conducted using questionnaires. The measuring scale of $\mathrm{o}$ is for mothers who visited ANC $<4$ times and 1 is for mothers who visited ANC $\geq 4$ times.

Family history of hypertension means a mother with a history of hypertension from her father/biological mother, biological grandparents. The data collection is done by questionnaire. The measuring instrument used is a questionnaire. Measuring scale of $\mathrm{o}$ is for mothers who do not have a family history of hypertension and 1 is for mothers who have a family history of hypertension.

History of hypertension refers to mothers with a history of hypertension before pregnancy. The data collection was done using questionnaires. Measuring scale of $\mathrm{o}$ is for mothers who do not have a history of hypertension and 1 is for mothers who have a history of hypertension.

History of diabetes mellitus refers to mothers with a history of diabetes mellitus during pregnancy. The data collection was done using questionnaires. The measuring scale of $\mathrm{o}$ is for mothers who have no 
history of diabetes mellitus and 1 is for mothers who have a history of diabetes mellitus.

Stress refers to a condition when mothers experience a negative emotional condition where a person experiences feelings of anxiety, irritability and overreacting to stressful situations. Data collection is done using questionnaires. The measuring scale of 0 is for low stress mothers and 1 is for high stress mothers.

\section{Study Instrument}

The data were collected by questionnaire. The validity tests were in the forms of content validity and face validity. The reliability testing in this study was carried out on 20 patients undergoing treatment at Surakarta City Hospital, both in the case population (10) and controls (10). Reliability testing was done by measuring variables using the SPSS 22 statistical program which can calculate total item correlations (200.20) and Cronbach alpha $(\geq 0.70)$.

\section{Data Analysis}

The data analysis was carried out using path analysis to determine the magnitude of the influence of determinants that influence, both direct or indirect ones. Path analysis steps in this study included model specifications, model identification, suitability of the model, parameter estimation and model specification.

\section{Research Ethics}

The research ethics include informed consent, anonymity, confidentiality and ethical clearance. The research ethics was obtained from Research Ethics Committee, Universitas Sebelas Maret, Surakarta, Central Java, with number 298.UN27.6.KEPK/ 2019.

\section{RESULTS}

\section{Univariate Analysis}

Table 1 showed the univariate analysis. Table 1 showed that mothers who have low education were 97 (48.5\%), primiparous was 87 (43.5\%). Mothers who visited ANC $\geq 4$ times were 128 (64\%). Mothers who did not have a family history of hypertension were 128 (64\%). Mothers who did not have a history of hypertension were 97 mothers (48.5\%). Mothers who did not have a history of diabetes mellitus were 120 mothers (60\%). Low-stress mothers were 108 (54\%).

Table 1. Univariate Analysis

\begin{tabular}{lcc}
\hline \multicolumn{1}{c}{ Variables } & n & \% \\
\hline Severe Preeclampsia & & \\
Non-severe Preclampsia & 150 & 75.0 \\
Severe Preclampsia & 50 & 25.0 \\
Age & & \\
20-34 years & 127 & 63.5 \\
$<20$ and $\geq 35$ years & 73 & 36.5 \\
Education & & \\
Low & 97 & 48.5 \\
High & 103 & 51.5 \\
Parity & 87 & 43.5 \\
1 & 113 & 56.5 \\
ANC Visit & & \\
<4 times & 72 & 36.0 \\
$\geq 4$ times & 128 & 64.0 \\
History of Hypertension & & \\
No & 97 & 48.5 \\
Yes & 103 & 51.5 \\
History of Diabetes & & \\
Mellitus & 120 & 60.0 \\
No & 80 & 40.0 \\
Yes & & \\
Stress & 108 & 540 \\
Low & 92 & 46.0 \\
\hline High & & \\
\hline
\end{tabular}

\section{Bivariate Analysis}

Table 2 showed the result of bivariate analysis. Table 2 showed that age $<20$ or $\geq 35$ years $(\mathrm{OR}=3.32 ; 95 \% \mathrm{CI}=1.71$ to 6.45 ; $\mathrm{p}<0.001$ ), had family history of hypertension $(\mathrm{OR}=2.44 ; 95 \% \mathrm{CI}=1.27$ to 4.71 ; $\mathrm{p}=0.010$ ), had history of hypertension $(\mathrm{OR}=4.14 ; 95 \% \mathrm{CI}=2.00$ to $8.54 ; \mathrm{p}$ $<0.001)$, had history of DM $(\mathrm{OR}=5.44$; 95\% $\mathrm{CI}=2.70$ to $10.94 ; \mathrm{p}<0.001)$, and high stress $(\mathrm{OR}=7.53 ; 95 \% \mathrm{CI}=3.49$ to 16.28 ; 
Journal of Maternal and Child Health (2019), 4(2): 126-135

https://doi.org/10.26911/thejmch.2019.04.02.08

$\mathrm{p}<0.001$ ) increased the risk of severe preeclampsia.

Table 2. The results of bivariate analysis

\begin{tabular}{|c|c|c|c|c|c|c|c|}
\hline \multirow[t]{2}{*}{ Variables } & \multicolumn{2}{|c|}{$\begin{array}{c}\text { Non-Severe } \\
\text { Preeclampsia } \\
\end{array}$} & \multicolumn{2}{|c|}{$\begin{array}{c}\text { Severe } \\
\text { Preeclampsia } \\
\end{array}$} & \multirow[t]{2}{*}{$\mathbf{O R}$} & \multirow[t]{2}{*}{ 95\% CI } & \multirow[t]{2}{*}{$\mathbf{p}$} \\
\hline & $n=150$ & $\%$ & $\mathrm{n}=50$ & $\%$ & & & \\
\hline Age & & & & & & 1.71 to 6.45 & \\
\hline 20-34 years & 106 & 83.5 & 21 & 16.5 & $3 \cdot 32$ & & $<0.001$ \\
\hline$<20$ or $\geq 35$ years & 44 & 60.3 & 29 & 39.7 & & & \\
\hline Education & & & & & & 0.09 to 0.42 & $<0.001$ \\
\hline Low & 59 & 60.8 & 38 & 39.2 & 0.20 & & \\
\hline High & 91 & 88.3 & 12 & 11.7 & & & \\
\hline Parity & & & & & & 0.08 to & $<0.001$ \\
\hline 1 & 50 & $57 \cdot 5$ & 37 & 42.5 & 0.17 & 0.36 & \\
\hline$>1$ & 100 & 88.5 & 13 & 11.5 & & & \\
\hline ANC & & & & & & 0.04 to 0.19 & $<0.001$ \\
\hline$<4$ & 34 & 47.2 & 38 & 52.8 & 0.09 & & \\
\hline$\geq 4$ & 116 & 90.6 & 12 & 9.4 & & & \\
\hline $\begin{array}{l}\text { Family history of } \\
\text { hypertension }\end{array}$ & & & & & & & \\
\hline No & 104 & 81.3 & 24 & 18.8 & 2.44 & 1.27 to 4.71 & 0.010 \\
\hline Yes & 46 & 63.9 & 26 & 36.1 & & & \\
\hline History of & & & & & & & \\
\hline hypertension & & & & & & 2.00 to 8.54 & $<0.001$ \\
\hline No & 85 & 87.6 & 12 & 12.4 & 4.14 & & \\
\hline Yes & 65 & 63.1 & 38 & 36.9 & & & \\
\hline History of DM & & & & & & 2.70 to & $<0.001$ \\
\hline No & 105 & 87.5 & 15 & 12.5 & 5.44 & 10.94 & \\
\hline Yes & 45 & 56.3 & 35 & 43.8 & & & \\
\hline Stress & & & & & & 3.49 to & \\
\hline Low & 98 & 90.7 & 10 & 9.3 & $7 \cdot 53$ & 16.28 & $<0.001$ \\
\hline High & 52 & 56.5 & 40 & 43.5 & & & \\
\hline
\end{tabular}

\section{Path Analysis}

Figure 1 depicted path model with estimation. Table 3 showed that there was a significant effect of parity, ANC, history of diabetes mellitus, history of hypertension, age, stress, education, and family history of hypertension. There was a relationship between severe preeclampsia and parity $(\mathrm{b}=-0.96$; CI $95 \%=-1.90$ to $-0.01 ; \mathrm{p}=$ 0.046), ANC ( $b=-1.98$; CI 95\%= -2.91 to 1.05; $\mathrm{p}<0.001)$, history of DM $(b=1.12$; CI $95 \%=0.21$ to $2.03 ; p=0.016$ ), history of hypertension $(b=1.54 ; \mathrm{CI} 95 \%=0.58$ to $2.51 ; \mathrm{p}=0.002)$, age $(\mathrm{b}=1.23 ; \mathrm{CI} 95 \%=0.31$ to $2.14 ; \mathrm{p}=0.008$, stress $(\mathrm{b}=1.58 ; \mathrm{CI}$ $95 \%=0.60$ to $2.56 ; \mathrm{p}=0.002)$, ANC through DM (b=-1.29; CI 95\%= -1.90 to 0.68; $\mathrm{p}<0.001$ ), education through ANC $(b=1.17$; CI $95 \%=0.56$ to $1.77 ; p<0.001)$, family history of hypertension through history of hypertension $(b=0.60$; CI $95 \%=$ 0.02 to $1.19 ; \mathrm{p}=0.042)$. 


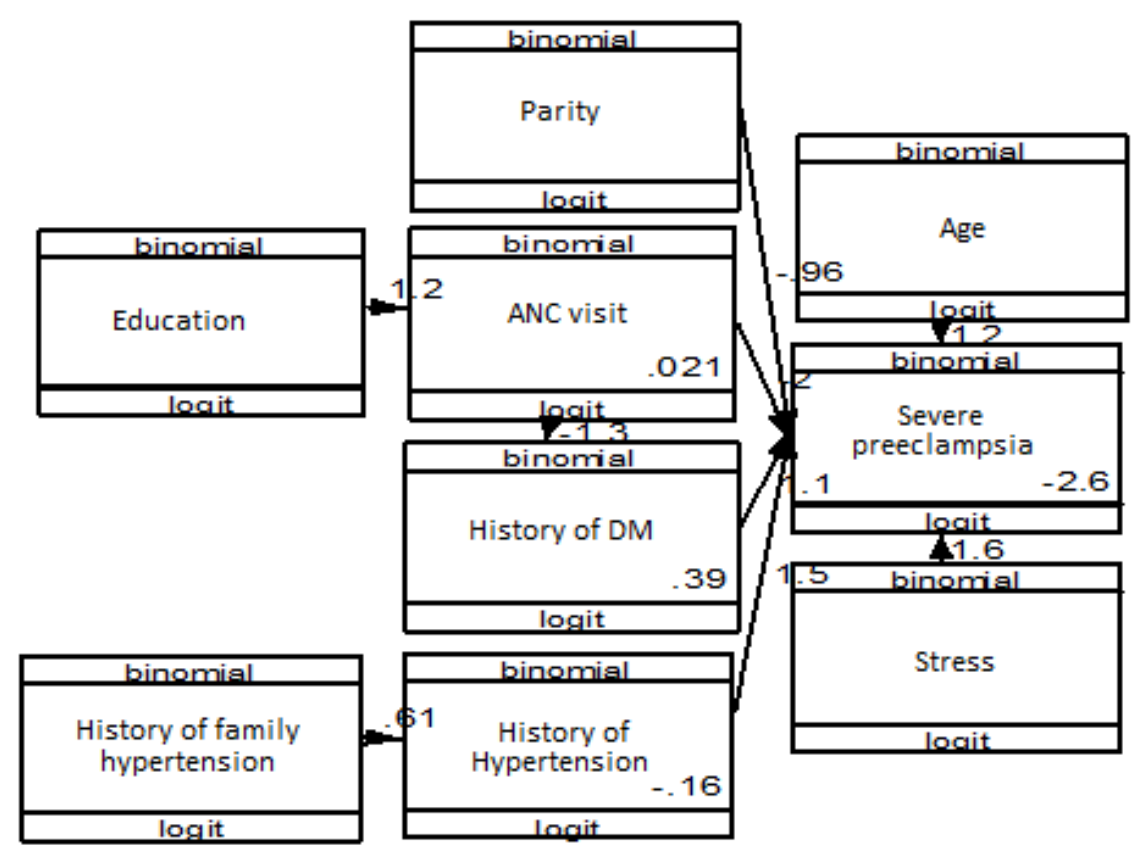

Figure 1. Path model with estimation

Table 3. The results of path analysis

\begin{tabular}{|c|c|c|c|c|c|c|}
\hline \multirow{2}{*}{$\begin{array}{c}\text { Dependent } \\
\text { Variable }\end{array}$} & & \multirow{2}{*}{$\begin{array}{l}\text { Independent } \\
\text { Variable }\end{array}$} & \multirow{2}{*}{$\begin{array}{c}\text { Path } \\
\text { Coefficient } \\
\text { (b) }\end{array}$} & \multicolumn{2}{|c|}{$95 \%$ CI } & \multirow[b]{2}{*}{$\mathbf{p}$} \\
\hline & & & & $\begin{array}{c}\text { Lower } \\
\text { Limit }\end{array}$ & $\begin{array}{c}\text { Upper } \\
\text { Limit }\end{array}$ & \\
\hline \multicolumn{7}{|l|}{ Direct Effect } \\
\hline Severe & $\leftarrow$ & Parity & 0.96 & -1.90 & -0.01 & 0.046 \\
\hline \multirow[t]{5}{*}{ Preeclampsia } & $\leftarrow$ & ANC & -1.98 & -2.91 & -1.05 & $<0.001$ \\
\hline & $\leftarrow$ & $\begin{array}{l}\text { History of diabetes } \\
\text { mellitus }\end{array}$ & 1.12 & 0.21 & 2.03 & 0.016 \\
\hline & $\leftarrow$ & $\begin{array}{l}\text { History of } \\
\text { hypertension }\end{array}$ & 1.54 & 0.58 & 2.51 & 0.002 \\
\hline & $\leftarrow$ & Age & 1.23 & 0.31 & 2.14 & 0.008 \\
\hline & $\leftarrow$ & Stress & 1.58 & 0.60 & 2.56 & 0.002 \\
\hline Indirect Effect & & & & & & \\
\hline $\begin{array}{l}\text { History of diabetes } \\
\text { mellitus }\end{array}$ & $\leftarrow$ & ANC & -1.29 & -1.90 & -0.68 & $<0.001$ \\
\hline ANC & $\leftarrow$ & Education & 1.17 & 0.56 & 1.77 & $<0.001$ \\
\hline $\begin{array}{l}\text { History of } \\
\text { hypertension }\end{array}$ & $\leftarrow$ & $\begin{array}{l}\text { Family history of } \\
\text { hypertension }\end{array}$ & 0.60 & 0.02 & 1.19 & 0.042 \\
\hline
\end{tabular}

\section{DISCUSSIONS}

\section{The relationship between age and severe preeclampsia}

The result of analysis showed that there was an effect of age on severe preeclampsia. This study showed that maternal age $<20$ or $\geq 35$ years old were 1.23 times more likely to had severe preeclampsia.

This study was in line with a study by Morikawa et al., (2013) which showed that $\geq 35$ years old mothers was the risk factor of severe preeclampsia. Maternal age $\geq 35$ years would increase the risk of preeclamp- 
sia by 1.8 times. The result of a study done by Kumari et al., (2016) stated that there was a relationship between age and preeclampsia. Mothers aged <20 years old were at risk of developing preeclampsia. Failure of normal trophoblast cell invasion could lead to mal adaptation of spiral arterioles, this was related to the causes of preeclampsia.

\section{The relationship between educa- tion and severe preeclampsia}

The result of analysis showed that there was an effect of education through ANC on the incidence of severe preeclampsia. Mother who had high education were 1.17 times more likely to conduct ANC visit.

This study was in line with a study by Muyunda et al., (2016) which showed that high maternal education level was a very significant and important factor in determining optimal use of ANC. The results of this study indicated that mothers who have a high level of education were more likely to have sufficient knowledge of ANC services and understand the importance of ANC and attend four recommended visits. Therefore, mothers who have higher education tend to use ANC services compared to mothers with low education. Maternal education has an indirect relationship with the incidence of severe preeclampsia, the higher the maternal education, the lower the risk of severe preeclampsia.

\section{The relationship between parity and severe preeclampsia}

The result of analysis showed that there was an effect of parity on the incidence of severe preeclampsia. Primiparous mother were 0.96 more likely to had severe preeclampsia.

This study was in line with a study by Pogacnik et al., (2018) which stated that there was a relationship between parity and severe preeclampsia. Primigravida mothers have 1.6 times higher risk than mothers with multigravida.

\section{The relationship between ANC visit and severe preeclampsia}

The result of analysis showed that there was an effect of ANC visit on severe preeclampsia. This showed that mothers who conduct ANC visits for $<4$ times were 1.98 times more likely to have severe preeclampsia.

This study was in line with a study by Ghi et al., (2018) which stated that there was a relationship between ANC visit and preeclampsia. Mothers who visit ANC in inadequate number have 12 times higher risk which was significantly higher than mothers who conduct ANC visit in sufficient numbers.

\section{The relationship between family history of hypertension and severe preeclampsia}

The result of analysis showed that there was an effect of family history of hypertension through history of hypertension on the incidence of severe preeclampsia. Mother with family history of hypertension were 0.60 time more likely to had history of hypertension.

This study was in accordance with a study by Ranasinghe et al., (2015) which stated that there was a relationship between family history of hypertension with a history of hypertension. The results of this study could be interpreted that family history of hypertension from parents would increase the risk to experience a history of hypertension in mothers by 1.28 times, while a family history of hypertension from grandparents would increase the risk to experience a history of hypertension in mothers by 1.34 times. Family history of hypertension has an indirect relationship with the incidence of severe preeclampsia, mothers who have a family 
history of hypertension would have a higher risk to have severe preeclampsia.

\section{The relationship between history of hypertension and severe pre- eclampsia}

The result of analysis showed that there was an effect of history of hypertension on the incidence of severe preeclampsia. Mother with history of hypertension was 1.54 times more likely to have severe preeclampsia.

This study was in line with a study by English et al., (2015) which stated that there was a significant relationship between history of hypertension and the incidence of preeclampsia. Mothers with history of hypertension were 1.38 times more likely to have severe preeclampsia.

\section{The relationship between history of diabetes mellitus and severe preeclampsia}

The result of analysis showed that there was an effect of history of diabetes mellitus on the incidence of severe preeclampsia. Mother who with history of DM was 1.12 times more likely to had severe preeclampsia.

This study was in accordance with a study done by Weissgerber and Mudd (2016) which stated that there was a relationship between history of diabetes mellitus and the incidence of preeclampsia. Mothers with history of diabetes mellitus were 2-4 times more likely to have preeclampsia than mothers who did not have history of diabetes mellitus.

\section{The relationship between stress and severe preeclampsia}

The result of analysis showed that there was an effect of stress on the incidence of severe preeclampsia. This showed that mothers who experienced severe stress were 1.58 times more likely to have severe preeclampsia.
This study was in line with a study done by $\mathrm{Yu}$ et al., (2013) which stated that there was a relationship between stress and the incidence of preeclampsia. Stress during pregnancy was a risk factor for the occurrence of preeclampsia in pregnancy up to 20 times. These findings underscore the importance of efforts to prevent, filter, and manage chronic hypertension, to reduce psychosocial stress, especially among women with chronic hypertension.

\section{REFERENCES}

Bdolah Y, Elchalal U, Natanson-yaron S, Bdolah-abram T, Greenfield C, Milwidsky A, Rana S, Ananth S, Yagel S and Hochner-celnikier D (2014). Relationship between nulliparity and preeclampsia may be explained by altered circulating soluble fms-like tyrosine kinase-1. Hypertens Pregnancy.doi:10.3109/10641955.2013.858745

Benli R A, Benli C N F, Usta T A, Atakul T, Koroglu M. (2014). Effect of Maternal Age on Pregnancy Outcome and Cesarean Delivery Rate. Journal of Clinical Medicine Research. doi: 10.14740/jocmr1904w.

Berry C, Atta MG (2016). Hypertensive disorders in pregnancy. Journal of Nephrology.doi:10.5527/wjn.v5.i5.418

Cohen W R (2014). Does maternal age affect pregnancy outcome. An International Journal of Obstetrics \& Gynaecology. doi: 10.1111/1471-0528. 12563.

Dinas Kesehatan Provinsi Jawa Tengah. (2018). Buku Saku Tahun 2017. http://dinkesjatengprov.go.id/v2018/ dokumen/bukusaku_2017/mobile/in dex.html \#p=26

English FA, Keny LC, Charty FP, Kenny LC (2015). Risk factors and effective management of preeclampsia. Inte- 
grated Blood Pressure Control. doi: 10.2147/IBPC.S50641.

Ghi T, Asta D (2018). Antenatal Care of Preeclampsia: From the Inverted Pyramid to the Arrow Model?. Fetal Diagnosis and Therapy. doi: 10.1159/000490047

Grum T, Seifu A, Abay M, Angesom T, Tsegay L (2017). Determinants of preeclampsia / Eclampsia among women attending delivery Services in Selected Public Hospitals of Addis Ababa, Ethiopia: a case control study. BMC Pregnancy and Childbirth. doi: 10.1186/s12884-017-1507-1

Gutaj P, Zawiejska A, Mantaj U, Wender E (2017). Determinants of preeclampsia in women with type 1 diabetes. The American Journal of Obstetrics \& Gynecology, (123456789). doi: 10.1007/s00592-017-1053-3.

Jeyabalan A (2013). Epidemiology of preeclampsia: impact of obesity. Nutrition Review. doi: 10.1111/ nure.12055

Kementrian Kesehatan RI (2017). Profil Kesehatan Indonesia Tahun 2016. Pusat Data dan Informasi Kemenkes. http://www.depkes.go.id/resources/d ownload/pusdatin/profilkesehatanindonesia/ProfilKesehatan Indonesia2016. pdf.

Kumari N, Dash K, Singh R (2016). Relationship between Maternal Age and Preeclampsia. IOSR Journal of Dental and Medical Sciences. doi: 10.9790/0853-1512085557.

Muyunda B, Markasa M, Jacob C, Musoda P, Michelo P (2016). Higher Educational Attainment Associated with Optimal Antenatal Care Visits among Childbearing Women in Zambia. Frontiers in Public Health. doi: 10.3389/fpubh.2016.00127.

Moon M, Odibo A (2014). First-trimester screening for preeclampsia: impact of maternal parity on modeling and screening effectiveness. The Journal of Maternal-Fetal and Neonatal Medicine, 7058: 1-6. doi: 10.3109/14767058.2014.978758.

Morikawa M, Yamada T, Yamada T, Sato S, Cho K, Minakami H (2013). Effects of nulliparity, maternal age, and prepregnancy body mass index on the development of gestational hypertension and preeclampsia. Hypertension Research in Pregnancy. doi: https://doi.org/10.14390/jsshp.1.75.

Pogacnik K, Bregar, Lucovnik M, Krajec M, Verdenik I, Blickstein I, Tul N (2018). The effect of interaction between parity, gestational diabetes, and pregravid obesity on the incidence of preeclampsia The Journal of Maternal-Fetal \& Neonatal Medicine. doi: 10.1080/14767058.2018.1509311.

Quan L, Xu Q, Zhang G, Wu L, Xu H (2018). An analysis of the risk factors of preeclampsia and prediction based on combined biochemical indexes. Kaohsiung Journal of Medical Sciences. doi: 10.1016/j.kjms.2017.10.001.

Ramesh K, Gandhi S, Rao V (2014). SocioDemographic and Other Risk Factors of Pre Eclampsia at a Tertiary Care Hospital, Karnataka: Case Control Study. Journal of Clinical and Diagnostic Research. doi: 10.7860/JCDR/2014/10255.480.

Ranasingh P, Cooray DN, Jayawardena R, Katulanda P (2015). The influence of family history of Hypertension on disease prevalence and associated metabolic risk factors among Sri Lankan adults. BMC Public Health. doi: 10.1186/s12889-015-1927-7.

Tessema GA, Tekeste A, Ayele TA (2015). Preeclampsia and associated factors among pregnant women attending 
antenatal care in Dessie referral hospital, Northeast Ethiopia: a hospitalbased study. BMC Pregnancy and Childbirth. doi: 10.1186/s12884-0150502-7

Weissgerber T, Mudd LM (2016). Preeclampsia and Diabetes. NIH Public Access. doi: 10.1007/s11892-015-0579-4.

Villa PM, Marttinen P, Gillberg J, Lokki AI, Majander K, Taipale P, Pesonen ARK, Laivuori $\mathrm{H}$ (2017). Cluster analysis to estimate the risk of preeclampsia in the high-risk Prediction and Prevent- ion of Preeclampsia and Intrauterine Growth Restriction (PREDO) study. Plos One. doi: 10.1371/journal.pone.0174399.

Yu Y, Zhang S, Wang G, Hong X, Mallow E B, Walker S O, Pearson C, Heffner L, Zuckerman B, Wang X (2013). The combined association of psychosocial stress and chronic hypertension with preeclampsia and chronic hypertension with preeclampsia. The American Journal of Obstetrics \& Gynecology. doi: 10.1016/ j.ajog. 2013.07.003. 